\title{
POTASH EXPLORATION IN NORTH AND SOUTH AMERICA
}

\author{
Daniel G. Rubiolo
}

\section{INTRODUCTION}

Potash is the common name given to a naturally occurring, reddish color, mixture of minerals sylvite $(\mathrm{KCl})$ and Halite $(\mathrm{NaCl})$ that form a rock named sylvinite. Equivalent percentage potassium oxide $(\mathrm{K} 2 \mathrm{O})$ is the common industry standard and grade of products are subdivided based on varying $\mathrm{K} 2 \mathrm{O}$ purity and particle size.

Potash is mined and processed in 13 countries (Canada, Belarus, Russia, Germany, Brazil, Chile, Spain, China, USA, Israel, Jordan, UK, and Ukraine). This commodity is consumed in more than 150 countries.

The potash beds within Canada are the world's single-largest source of mineable potash, comprising over $50 \%$ of the world's known potash reserves. Canada is the largest producer (33\% of world production) and major competitors are Russia (19\%), Belarus (16\%), Germany (11\%), Israel (6\%), others (11\%) and USA $(3 \%)$.

As a comparison Brazil imports $70 \%$ of the fertilizer it consumes and the agri-business accounts for $25 \%$ of the Brazilian economy. Brazil is world's third-largest potash consumer. In 2006, Brazilian farmers used 3.5 million tonnes of potash, after China with 5.6 million tones, and the United States with 4.7 million tonnes.

\section{GENERALITIES FOR POTASH DEPOSITS IN SASKATCHEWAN, CANADA}

As well as being the world's largest source of potash, the ore found in Canada exhibits good continuity and the potash beds in Saskatchewan typically lie at depths of less than 1100 meters, facilitating cost-effective underground mining not possible at greater depths. Moreover, the grade of ore found within the Prairie Evaporite Formation is relatively high, ranging from $20 \%-35 \% \mathrm{~K} 2 \mathrm{O}$, compared to areas of Europe and Mexico where grading averages $19 \% \mathrm{~K} 2 \mathrm{O}$. This makes it possible for companies to economically extract viable potash quantities from relatively limited hectares of land. Potash beds in Saskatchewan's Prairie Evaporite Formation are flat lying, undeformed and, therefore, not exposed to external complexities that would otherwise increase production costs relative to other international deposits.

Saskatchewan's potash deposits are part of a vast potash-bearing region extending across southern Saskatchewan into Manitoba, and to the south into the USA. The potash occurs near the top of a thick sequence of halite and anhydrite that constitute the
Prairie Evaporite, Devonian age, ca. 380 Ma. This formation typically occurs at a depth of 400 to 2700 $\mathrm{m}$ below ground and attains a maximum thickness of $215 \mathrm{~m}$. The upper $60 \mathrm{~m}$ of the formation contains three distinct potash-bearing members: Patience Lake, Belle Plaine and Esterhazy.

Each member contains one or more potash-bearing beds (up to $7 \mathrm{~m}$ thick), which are typically intercalated with halite that ranges up to $45 \mathrm{~m}$ thick. These halite beds are referred to as "salt backs". Since the potash units of Saskatchewan are sub-horizontal, the general characteristics of the units can be reasonably extrapolated from wells separated by several kilometers and seismic data.

In general Potash deposits located at depths less than $1100 \mathrm{~m}$ below surface are exploited by conventional mining method. Solution mining methods are typically used for those deposits, which are deeper than 1100 meters.

\section{APPLICATION OF GEOSCIENCE TO POTASH EXPLORATION IN SASKATCHEWAN, CANADA}

In general potential areas used to have wells drilled for oil and gas exploration without coring recover through the potash bearing intervals. As a preliminary information could be accessed end of hole depth and bottom of intersected geological formation. Additional well information data can be, assay results, geological and stratigraphical logs.

By using down hole geophysical logs is possible to estimate thickness, calculate apparent $\mathrm{K} 2 \mathrm{O} \%$, potential tonnage estimation, target generation and ranking.

2D and 3D seismic surveys are useful to identify anomalies, and density, inferring carnallite $(\mathrm{KCl}$. $\mathrm{MgCl} 2.6 \mathrm{H} 2 \mathrm{O})$ and sylvite $(\mathrm{KCl})$ calculation.

Disturbances affect stratigraphy and exploitability of the potash-bearing rocks.

In general, a disturbance that affects the normal character of the sylvinite-bearing beds is considered an "anomaly" or altered zone, which is not suitable for mining. Potash-bearing beds may be affected by three types of anomalies (1: Salt dissolution and collapse, 2: Leach anomalies, and 2: Washout anomalies). These anomalies range from localized features less than a square kilometer in extent to disturbances that are regional (i.e., several square kilometers in extent). This concept is typical for Saskatchewan potash mining properties, and could be consider and applied globally to any exploration due diligence.

The impact of these types of anomalies on mining 
operations is that the grade of the potash ore being sent to the mill drops as mining cuts through anomalous ground, or that a portion of the potash ore reserve is left in the ground as mining operations abandon the anomalous ground as a safety pillar surrounding it.

Generally, a combination of surface reflection seismic (2D and 3D), careful examination of surface drill holes, underground ("in-seam") geophysics, and geological observations of mining rooms is sufficient to identify potentially anomalous ground.

Encountering unexpected anomalies can create ore value loss for half of mine panel, with estimated losses of hundred of millions of dollars. Determining anomalies can avoid flooding remediation costs. To mitigate these risks are used 2D and 3D seismic surveys. In general costs for these surveys are of one order of magnitude smaller than value loss and cost associated with extra development and ground control.

\section{POTASH DEPOSITS IN NORTH AND SOUTH AMERICA}

Canada: Elk Point potash basin, Saskatchewan; Millstream basin, New Brunswick.

USA: Paradox basin, Utah; Carlsbad deposit, New Mexico, Michigan basin, etc:

Mexico: Cerro Prieto, Baja California.

Peru: Bayobar potash brines and phosphate deposits, Sechura desert.

Chile: Caliche ore and salar brines, Atacama (nitrates, iodine, Li, B, K)

Argentina (Salar/brines at Hombre Muerto, Rincón, Olaroz, K, Li, B in Salta and Jujuy. Rio Colorado underground solution mining project, Mendoza).

Bolivia: Salar de Uyuni, K, Li, B.

Brazil: Taquari-Vassouras (Sergipe); Fazendinha - Arari (Amazonas basin); El Salvador potash project (Bahia); Santana-Urucum (Mato Grosso); and several littoral areas explored for oil and gas, which are associated to salt stocks.

\section{RECOMMENDATIONS FOR EXPLORING NEW AREAS}

Here are pointed out some aspects in potash exploration successfully applied in Saskatchewan, Canada. They can be applied in order to conduct an effective review and due diligence in new areas. Following points can be considered during first phases of exploration for underground potash deposits:

a) Gain access to historical data and related documentation.

b) Review and GIS spatially compile historical source of documentation.

c) Identify areas with low potential that can be ignored early on, in order to focus activities.

e) Review geology, mineralization and drilling results, if they are available. f) Analyze drill hole core data for the presence of limestone formations on top and on the bottom, salt back thickness, potash layers, anomalies, etc.

g) Quality Assesment/ Quality Control's review for sampling and programs discussion.

h) Geophysical review and consider gamma ray, seismic, old core data and old geophysical results.

i) Analyze any environmental considerations including carnalite contents, ore grades, clay/insoluble's contents, porosity, permeability, other hydro-geological criteria and anomalies. These points are considered for processing insoluble and geotechnical risks.

\section{REFERENCES}

CARR, B. J \& HAJNAL, Z., 1995. Compressional and shear wave seismic studies in the Williston Basin of central Saskatchewan. (Ed) Hunter, L.D.V \& Schalla, R.A., Special Publication Saskatchewan Geological Society, vol. 12, pp.47-56.

CUNNINGHAM, C. G; ZIENTEK, M. L; BAWIEC, W.J \& ORRIS, G. J., 2005. Geology and nonfuel mineral deposits of Latin America and Canada. Open-File Report - U. S. Geological Survey, Report: OF 2005-1294-B, 104 pp.

DA COSTA, A. M.\& FAIRHURST, C., 1985. Comparison of numerical modeling with predictions from laboratory tests and field observations of deformation in a potash mine in Sergipe, Brazil. Proceedings - Symposium on Rock Mechanics, vol.26, pp.239-249, Rapid City, SD.

FUZESY, A. 1982. Potash in Saskatchewan. Saskatchewan Energy and Mines. Department of Mineral Resources, Regina, SK.

GARRETT, D.E. 1996. Potash: deposits, processing, properties, and uses. Chapman \& Hall, London \& New York.

GIBSON, C., PARASZCZYNEC, E. \& HARILDSTAD, 2010. Potash deposits of the world. North Rim Exploration Ltd., Geomatic poster, Saskatoon. SK.

KELLY, C; PERZ, M J; HARGREAVES, B., 2008. High resolution imaging of potash mines using exploration-scale reflection seismic measurements. Conference, Seismological Society of America. Seismological Research Letters, vol. 79, no. 2, pp.280.

LEFOND, S. J., 1969. Handbook of World Salt Resources. Plenum Press, 384p., New York.

LEFOND, S. J., 1975. Industrial Minerals and Rocks. American Institute of Mining, Metallurgical, and Petroleum Engineers, 360p. New York.

MELO DE OLIVEIRA, L. A., 2009. Potássio. Departamento Nacional de Produção mineral, abst. http://www.dnpm.gov.br/ mostra_arquivo.asp? IDBancoArquivoArquivo $=4381$

NAVA, D. B.; HORBE, M. A., 2008. As reservas de potassio do Amazonas no contexto do desenvolvimento sustantavel da Amazonia e do Brasil. Sociedade Brasileira de Geologia, vol. 44, abst. Porto Alegre.

STONE, K., 2009. Potash Outlook, Presentation to The Fertilizer Institute's Fertilizer Outlook and Technology Conference, Tampa, Florida, October 29, 2009. 